\title{
Serum antinuclear autoantibodies are associated with measures of oxidative stress and lifestyle factors - analysis of LIPIDOGRAM2015 and LIPIDOGEN2015 studies.
}

\author{
Type \\ Research paper
}

\section{Keywords}

antinuclear autoantibody, oxidative stress, lifestyle diseases, reactive oxygen species

\begin{abstract}
Introduction

Oxidative stress is one of many factors suspected to promote antinuclear autoantibody (ANA) formation. Reactive oxygen species can induce changes in the antigenic structure of macromolecules, causing the immune system to treat them as "neo-antigens" and start production of autoantibodies. This study was designed to evaluate the relationship between oxidative stress markers, lifestyle factors and the detection of ANA.
\end{abstract}

Material and methods

We examined measures of oxidative stress indices of free-radical damage to lipids and proteins, such as total oxidant status (TOS), concentration of protein thiol groups (PSH), and malondialdehyde (MDA), activity of superoxide dismutase (SOD) in in 1731 serum samples. The parameters of the nonenzymatic antioxidant system, such as total antioxidant status (TAS) and uric acid concentration (UA), were also measured and the oxidative stress index (OSI -index) was calculated. All samples were tested for the presence of ANA using an indirect immunofluorescence assay (IIFA).

Results

The presence of ANA in women was associated with lower physical activity $(p=0.036)$, less frequent smoking $(p=0.007)$ and drinking of alcohol $(p=0.024)$ accompanied by significant changes in SOD isoenzymes activity $(p<0.001)$ and a higher uric acid $(U A)$ concentration $(p<0.001)$. In ANA positive males we observed lower concentrations of PSH $(p=0.046)$ and increased concentrations of MDA $(p=0.047)$.

\section{Conclusions}

The results indicate that local oxidative stress may be associated with increased probability of ANA formation in a sex-specific manner. 


\section{Serum antinuclear autoantibodies are associated with measures of oxidative stress and lifestyle factors - analysis of LIPIDOGRAM2015 and LIPIDOGEN2015 studies.}

Paweł Krzemieńn ${ }^{1 *}$, Sławomir Kasperczyk ${ }^{2}$, Maciej Banach ${ }^{3 *}$, Aleksandra Kasperczyk ${ }^{2}$, Michał Dobrakowski ${ }^{2}$, Tomasz Tomasik ${ }^{4}$, Adam Windak ${ }^{4}$, Mirosław Mastej ${ }^{5}$, Alberico Catapano ${ }^{6}$, Kausik K.

Ray $^{7}$, Dimitri P. Mikhailidis ${ }^{8}$, Peter P. Toth ${ }^{9}$, George Howard ${ }^{10}$, Gregory Y. H. Lip ${ }^{11}$, Maciej Tomaszewski $^{12}$, Fadi J. Charchar ${ }^{13}$, Naveed Sattar ${ }^{14}$, Bryan Williams ${ }^{15}$, Thomas M. MacDonald ${ }^{16}$, Peter E. Penson ${ }^{17}$, Jacek J. Jóźwiak ${ }^{18}$ on behalf of the LIPIDOGRAM2015 Investigators**

1. Euroimmun Polska Sp. z o.o., Wroclaw 50-543, Poland

2. Department of Biochemistry, Faculty of Medical Sciences in Zabrze, Medical University of Silesia, Katowice 40-055, Poland.

3. Department of Hypertension, Medical University of Lodz, Łódź 90-647, Poland

4. Department of Family Medicine, Jagiellonian University Medical College, Krakow 31-008, Poland

5. Mastej Medical Center, Jasło 38-200, Poland

6. Department of Pharmacological Sciences University of Milano and Multimedica IRCCS, Milano 20153, Italy

7. Imperial Centre for Cardiovascular Disease Prevention, Department of Primary Care and Public Health, Imperial College, Kensington, London W6 8RP, UK

8. Department of Clinical Biochemistry, Royal Free Hospital, University College London, London NW3 2QG, UK

9. Cicarrone Center for the Prevention of Cardiovascular Disease, Johns Hopkins University School of Medicine, Baltimore MD 21205-2196, Maryland and CGH Medical Center, Sterling, Illinois IL 61081, USA

10. Department of Biostatistics, School of Public Health of Alabama at Birmingham, Birmingham AL 35294-0022, USA 
11. Liverpool Centre for Cardiovascular Science, University of Liverpool and Liverpool Heart \& Chest Hospital, Liverpool L14 3PE, United Kingdom; and Department of Clinical Medicine, Aalborg University, Aalborg 9000, Denmark

12. Division of Cardiovascular Sciences, Faculty of Biology, Medicine and Health, University of Manchester, Manchester M13 9NT, UK

13. School of Health and Life Sciences, Federation University Australia, Ballarat VIC 3350, Victoria, Australia

14. Institute of Cardiovascular and Medical Science, University of Glasgow, Glasgow G12 8TA, UK

15. NIHR University College London Biomedical Research Centre, University College London and University College London Hospitals NHS Foundation Trust, London W1T 7DN, UK

16. MEMO Research, University of Dundee, Ninewells Hospital and Medical School, Dundee DD1 9SY, UK

17. School of Pharmacy and Biomolecular Sciences, Liverpool John Moores University, Liverpool L3 5UX, UK; and Liverpool Centre for Cardiovascular Science, Liverpool L7 8TX, UK

18. Department of Family Medicine and Public Health, Faculty of Medicine, University of Opole, Opole 45-040, Poland

\section{*Corresponding author:}

- Pawel Krzemień, MSc, Euroimmun Polska Sp. z o.o., 2a Widna St., 50-543 Wroclaw, Poland. Phone: +48 509657 480; Fax: +48 713730011 ; E-mail: p.krzemien@euroimmun.pl 


\section{Abstract:}

Introduction: Oxidative stress is one of many factors suspected to promote antinuclear autoantibody (ANA) formation. Reactive oxygen species can induce changes in the antigenic structure of macromolecules, causing the immune system to treat them as "neo-antigens" and start production of autoantibodies. This study was designed to evaluate the relationship between oxidative stress markers, lifestyle factors and the detection of ANA.

Material and methods: We examined measures of oxidative stress indices of free-radical damage to lipids and proteins, such as total oxidant status (TOS), concentration of protein thiol groups (PSH), and malondialdehyde (MDA), activity of superoxide dismutase (SOD) in in 1731 serum samples. The parameters of the non-enzymatic antioxidant system, such as total antioxidant status (TAS) and uric acid concentration (UA), were also measured and the oxidative stress index (OSI -index) was calculated. All samples were tested for the presence of ANA using an indirect immunofluorescence assay (IIFA).

Results: The presence of ANA in women was associated with lower physical activity ( $\mathrm{p}=0.036)$, less frequent smoking $(\mathrm{p}=0.007)$ and drinking of alcohol $(\mathrm{p}=0.024)$ accompanied by significant changes in SOD isoenzymes activity $(\mathrm{p}<0.001)$ and a higher uric acid (UA) concentration ( $\mathrm{p}<0.001)$. In ANA positive males we observed lower concentrations of PSH ( $\mathrm{p}=0.046)$ and increased concentrations of $\operatorname{MDA}(\mathrm{p}=0.047)$.

Conclusions: The results indicate that local oxidative stress may be associated with increased probability of ANA formation in a sex-specific manner.

Keywords: antinuclear autoantibody, oxidative stress, lifestyle diseases, reactive oxygen species, 
List of Abbreviations: AAb - autoantibodies, AC - anti-cell, AD - Autoimmune diseases, AMA Antimitochondrial antibodies, ANA - anti-nuclear antibody, BMI - body mass index, CFPiP College of Family Physician in Poland, CVD - cardiovascular diseases, DFS70 - dense fine speckled 70kDa, HbA1c - Hemoglobin A1c, HDL - high-density lipoprotein cholesterol, Hep-2 - human laryngeal carcinoma cell line, HPLC - high-performance liquid chromatography, ICAP - International Consensus on ANA patterns, IFA - indirect immunofluorescence assay, LEDGF/p75 - lens epithelium-derived growth factor p75, LDL - low-density lipoprotein cholesterol, MDA malondialdehyde, NAAb - natural autoantibodies, OSEs - oxidation-specific epitopes, OS - oxidative stress, OSI-index - oxidative stress index, OxPL - oxidized phospholipids, PoLA - Polish Lipid Association, PRR - pattern recognition receptors, PSH - protein thiol groups, RA - rheumatoid arthritis, ROS - Reactive oxygen species, SARD - Systemic Autoimmune Rheumatic Diseases, SLE systemic lupus erythematosus, SSc - systemic sclerosis, SOD -superoxide dismutase, TAC - total antioxidant capacity, TC - total cholesterol, TG - triglycerides, TOS - total oxidant status, UA - uric acid, WHR - waist-hip ratio

Word count: 8902 (3685 without tables, figures and references)

\section{Number of tables: 5}

\section{Number of figures: 1}




\section{Introduction}

Nowadays, clinical investigations have spread across various areas of research fields $[1,2]$. Recently, clinical research has also considered the interesting topic of evaluating the role of oxidative stress (OS) in the development and progression of auto-immune diseases (ADs). Over 81 disorders are classified as $\mathrm{AD}$ and occur when an immune response to self-antigens results in damage or dysfunction to tissues [3]. ADs include a very diverse range of pathophysiological mechanisms and clinical consequences [3]. Regardless of the clinical picture, all ADs go through sequential phases of asymptomatic initiation and propagation, which may be accompanied by the presence of autoantibodies $(\mathrm{AAb})[4]$. AAb are a serological hallmark of $\mathrm{AD}$ and detection of $\mathrm{AAb}$ is often used to establish an early diagnosis in patients with clinical symptoms. However, AAb are often found in otherwise healthy individuals, but usually with low titers [5-7]. The etiology of AAb formation is not yet fully understood. There are many suspected factors that increase the risk of developing AAb including sex (more common in women) [6,8-10], genetic predisposition (most of the polymorphisms are located in regulatory regions of genes whose products are believed to play roles in immune responses) $[4,11,12]$, defective removal of apoptotic cells [13-18] and various environmental factors such as infections [19,20], oxidative stress [21-26], physical and chemical agents [15,21,27-29], as well as stressful life events [30]. However, regardless of the initial cause, the development of autoimmunity always occurs when there is breakdown in the regulation of B-cell or T-cell activation threshold and abnormal survival of autoreactive lymphocytes [4,31-39].

As mentioned above, one of the factors that may play a role in the development and course of AD is oxidative stress. Reactive oxygen species (ROS), present in acute or chronic OS, can lead to changes in the antigenic structure of macromolecules, causing the immune system to treat them as "neo-antigens" [16,32,35,40-45]. Because the antigens are products of oxidation, e.g. lipid peroxidation in the case of oxidized phospholipids (OxPL) and malondialdehyde-modified structures [46-48], or direct oxidative damage of proteins [49-51], we refer to them oxidation-specific epitopes (OSEs). In recent years it has become increasingly apparent that OSEs are recognized by the pattern recognition receptors (PRR) of the innate immune system [16,17,44,46,52]. It is thought that the 
remaining mechanisms of the innate immune system )molecular mimicry, epitope spreading and natural autoantibody (NAAb) production) play a pivotal role in the process of AAb formation $[4,23,24,41,53]$. For example Chou et al have shown that approximately $30 \%$ of all natural IgM antibodies, secreted by a subset of B1 cells target OSEs [44]. Epitope spreading (also epitope drift) is the spread of antigenicity from a given epitope to other parts of the protein or other proteins $[41,43]$. Thus, altered molecules, with sufficient homology to the native protein antigens, can result in the production of specific autoantibodies and lead to the development of AD[41,42,44,54-64]. Systemic autoimmune rheumatic diseases (SARDs) are an important group of ADs. According to current recommendations, when diagnosis of a SARD is suspected, the indirect immunofluorescence assay (IFA), using human epithelial larynx cancer cell line (HEp-2) as a substrate, is the gold standard screening test [65-70]. This approach determines the concentration of antinuclear antibodies (ANA) and the type of pattern staining. When high autoantibody titers are detected and are accompanied by clinical signs, connective tissue disease is very likely [70,71].

Previous studies have shown that patients with clinical manifestations of SARD and high titers of ANA also have increased OS [41,72]. Recent research has demonstrated that several biomarkers of OS (such as malondialdehyde (MDA), a marker of lipid peroxidation) are found at higher levels in the blood of systemic sclerosis (SSc) and rheumatoid arthritis (RA) patients than in controls $[49,73,74]$. Conversely, the concentration of protein thiol groups (PSH) and the activity of superoxide dismutase (SOD) have been shown to be decreased in RA, SSc and systemic lupus erythematosus (SLE) [74-80]. These observations are consistent with enhanced inflammation, initiated by an autoimmune response. However, it is not known whether the presence of autoantibodies, at low titres is associated with changes in OS markers. Nor is it clear whether OS contributes to AAb the formation. Therefore, this study was designed to evaluate the relationship between OS markers and the detection of ANA.

\section{Materials and methods}

A simplified scheme of the study is shown in Figure 1. 


\section{Design}

A nationwide observational, cross-sectional study was carried out in Poland in the fourth quarter of 2015 and the first and second quarters of 2016.

\section{Sampling}

This study is part of a large research program "Nationwide study of cardiovascular health in primary care in Poland - LIPIDOGRAM2015 and LIPIDOGEN2015", the design and rationale of which have been described in detail previously by Jóźwiak et. Al [81]. Briefly, the recruitment was carried out by 438 primary care physicians in 16 major administrative regions of Poland. Physicians/investigators were randomly selected from the Medical Data Management database. The expected number of patients recruited for LIPIDOGRAM2015 study (consecutive samples) was $13,000-14,000$ with a random sample of $13-15 \%(1,700-2,000)$ enrolled to the LIPIDOGEN2015 sub study. The program only covered adult patients over 18 years old. Each patient had to complete a questionnaire concerning their medical and family history, concomitant diseases and pharmacotherapy as well as lifestyle factors like alcohol consumption, tobacco smoking, physical activity and use of diet ( i.e. hypolipemic, hypoglycaemic, hypotensive diets). The following criteria were used in the question on alcohol consumption: moderate drinkers - persons consuming alcohol at a rate of 1-2 units/day (women) or 1-3 units/day (men), with the following conversion factor applied: 1 unit $=10-15 \mathrm{~g}$ ethanol $=250 \mathrm{ml}$ beer $($ glass $)=150 \mathrm{ml}$ wine $($ glass $)=30 \mathrm{ml}$ vodka (glass); heavy drinkers - people who consume alcohol in quantities greater than those assumed for moderate drinkers and persons who do not consume alcohol at all, or persons who consume alcohol occasionally in amounts significantly less than those assumed for persons with moderate alcohol consumption. The following criteria were used for the tobacco smoking question: smokers - those who had consistently smoked at least 1 cigarette/week in the period preceding the survey; former smokers - those who had permanently given up smoking in at least the last 3 months preceding the survey; non-smokers - those who had never smoked a cigarette. The following criteria were used in the physical activity question: regular physical effort - increased activity of the musculoskeletal system, regularly for $2-2.5 \mathrm{~h} / \mathrm{week}$, defined as exercising, walking, running, swimming, playing team games, dancing, and doing housework or 
household chores; or no regular physical activity - people who do not meet the criteria of regular physical activity; or others who did not provide detailed information on the level of their physical activity. In the question concerning the use of diet (hypolipemic, hypoglycaemic, hypotensive) the following criteria were used: Use of an appropriate diet - regular consumption of varied low cholesterol foods, moderate consumption of medium cholesterol foods, reduced consumption of saturated fats - in favor of monounsaturated and polyunsaturated fats, reduced consumption of carbohydrates and sweetened drinks, reduced consumption of table salt, increased consumption of fish, increased consumption of fruit and vegetables and fibre-rich foods or no use of an appropriate diet - those not meeting the criteria for following an appropriate diet. Anthropometric measurements (height, body weight, waist circumference, and hip circumference) were performed at the doctor's office. For all enrolled patients, serum samples were obtained after $\geq 12 \mathrm{~h}$ of fasting. On the same day, measurements of blood pressure, heart rate, and fasting glucose were obtained together with the lipid profile. For the LIPIDOGEN2015 sub-study, saliva samples for DNA isolation and blood samples for measurement of glycated hemoglobin, oxidative stress parameters, autoantibody levels, and inflammatory cytokine and apolipoprotein profiles were collected.

For this study we used 1731 serum samples from the abovementioned LIPIDOGEN2015 substudy. The tested group included 1043 women and 688 men. The blood samples were transferred in cooled containers $\left(-20^{\circ} \mathrm{C}\right)$ to a central laboratory (Silesian Analytical Laboratories - SLA in Katowice, Poland) for biochemical analyses and then to the autoimmune laboratory (Euroimmun Poland Ltd. Customer Training Laboratory in Wroclaw, Poland) for ANA determination.

\section{Laboratory analyses}

Measurements of total cholesterol (TC), triglycerides (TG), high-density lipoprotein cholesterol (HDL-C), and low-density lipoprotein cholesterol (LDL-C) (made with direct immunological measurement) were performed and carried out using the same methodology by the Siemens Advia 1800 analyser and Siemens reagents (Munich, Germany), within $12 \mathrm{~h}$ of obtaining the blood sample. Fasting glycaemia was measured using Bionime glucometers (Taichung City, Taiwan) 
and Rightest strip tests (Taichung City, Taiwan). HbA1c was assessed using high-performance liquid chromatography (HPLC) performed by Variant II Turbo (Bio-Rad, Hercules, California, USA).

To quantify the intensity of oxidative stress, indices of free-radical damage to lipids and proteins, and enzymatic and non-enzymatic antioxidant system parameters in serum and erythrocytes were measured. In serum, indices of free-radical damage to lipids and proteins included: total oxidant status (TOS) [82], protein thiol groups (PSH) [83] and the concentration of malondialdehyde (MDA) [84].The activity of superoxide dismutase (SOD) [85] was determined in serum. In addition, parameters of non-enzymatic antioxidant system, such as total antioxidant capacity (TAC) [86] and the concentration of uric acid (UA) were also determined. The oxidative stress index (OSI-index) was defined as the ratio of the TOS level to TAS level. Specifically, OSI-index (arbitrary unit) $=$ TOS $\left(\mu \mathrm{mol} \mathrm{H}_{2} \mathrm{O}_{2} \mathrm{Eq} / \mathrm{L}\right) / \mathrm{TAS}(\mu \mathrm{mol}$ Trolox Eq/L)[82]

ANA were detected using an indirect immunofluorescence assay (IFA) employing human laryngeal carcinoma cells (HEp-2) and commercially available Euroimmun Medizinische Labordiagnostika AG (Lübeck, Germany) test kits Mosaic Basic Profile 3 (catalogue number FC 1800-2010-3). Sample incubation was carried out manually, according to the manufacturer's instructions, except for the fact that 998 samples were diluted with a threshold cut-off 1:160 as recommended by the current guidelines [68] and 733 patient samples were diluted with a threshold cut-off 1:100 as recommended by the test kit manufacturer's instructions. The samples were divided into two groups randomly. The results were evaluated on a EUROstar III fluorescence microscope (CarlZeiss Oberkochen, Germany). The test results included a qualitative assessment of the presence of ANA, estimation of antibody titer, and determination of the characteristic pattern according to the (ICAP) nomenclature [67]. The results of IFA were collected and stored as digital images.

\section{Statistical analysis}

Statistical analyses were performed using Statistica 13.3 (StatSoft, Tulsa, USA). Data are expressed as mean $\pm \mathrm{SD}$ (normal distribution) and as median and range (nonparametric distribution) for continuous variables, and as a percentage for categorical variables. Univariate comparison of 
markers related to autoimmune diseases according to clinical variables was performed using the Mann-Whitney-U test for nonparametric variables or the $\chi 2$ test/Fisher exact tests where appropriate. A two-sided $\mathrm{p}<0.05$ was considered to indicate statistical significance.

\section{Ethical approval}

The study was performed in accordance with the principals outlined in Declaration of Helsinki[87]. Every patient gave a written informed consent to participate. The study was approved by the Bioethical Committee of the Chamber of Physicians (No.K.B.Cz.-0018/2015).

\section{Results}

The study included 1731 patients attending primary health care practices (1043 women and 688 men). 1098 people were diagnosed with hypertension, coronary artery disease, dyslipidemia, diabetes, atrial fibrillation, kidney disease or stroke. 649 people were apparently healthy individuals. The mean age of participants was $51 \pm$ (SD 13 years) and $60.25 \%$ were female (Table 1). The body mass index (BMI) indicated that the participants were on average slightly overweight [88], and the average waist-hip ratio (WHR) was above the normal range for both men and women [89].

The ANA test was positive in 260 patients (15.0\% of the entire study population). A total of 201 patients had antibody titers determined at screening levels of 1:100 $(n=116)$ or 1:160 $(n=85)$. Only 59 patients had ANA titer higher than the cut-off threshold (1:100 or 1:160).

The study cohort was analysed to explore associations between lifestyle factors, lifestyle diseases and the occurrence of ANA. It was found that ANA are more frequently detected in women (71.9\% vs. $28.1 \%$ p $<0.001)$ than in men. The results presented in Table 2 show that the occurrence of ANA in women is associated with lower physical activity $(\mathrm{p}=0.036)$, less frequent smoking $(\mathrm{p}=0.007)$ and low alcohol consumption ( $\mathrm{p}=0.024)$. In case of men, none of the lifestyle-related aspects analyzed were associated with the presence of ANA. Lifestyle diseases were not associated with the presence of ANA in either women or men. 
The analysis of the association between oxidative stress markers and the occurrence of ANA by sex of the subjects showed that ANA positive men had a significant 6\% decrease in PSH concentration $(\mathrm{p}=0.046)$ and an $11 \%$ increase in MDA concentration $(\mathrm{p}=0.047)$ compared with ANA negative men. In the ANA positive women, on the other hand, changes in the activity of SOD isoenzymes were observed (6\% increase in MnSOD activity ( $\mathrm{p}=0.001)$ and $8 \%$ decrease in CuZnSOD activity $(\mathrm{p}<0.001))$. Moreover, in ANA positive women, the concentration of UA was $10 \%$ higher than in women without these AAbs. The results for individual parameters are presented in Table 3.

We also investigated whether the specific pattern types in ANA positive patients differ in relation to sociodemographic parameters and markers of oxidative stress. For most ANA patterns, no significant differences were observed. However, several observations warrant further investigation. In particular, AC-2 positive samples showed a 7\% lower activity of the CuZnSOD isoenzyme ( $\mathrm{p}=0.044)$, a 5\% lower concentration of UA $(\mathrm{p}=0.035)$ and a lower TAC $(\mathrm{p}=0.007)$ compared with the other ANA positive samples. Autoantibodies associated with the AC-21 pattern were observed more commonly in individuals with less physical activity $(\mathrm{p}=0.005)$, diagnosed coronary artery disease $(\mathrm{p}=0.013)$, previous myocardial infarction $(\mathrm{p}=0.049)$ or dyslipidemia $(\mathrm{p}=0.032)$ than in other ANA positive patients. In AC-21 samples, a lower concentration of PSH was also observed $(\mathrm{p}=0.038)$. In men, the AC9/AC10 pattern was very common $(\mathrm{p}<0.001)$ and the AC4/AC5 pattern was much less common $(\mathrm{p}=0.027)$ compared to other ANA positive patients. In patients displaying the AC4/AC5 pattern, a lower intensity of oxidative stress (a 32\% lower OSI-index) was observed compared with other ANA positive patients $(\mathrm{p}=0.023)$. All the selected parameters for which significant differences were observed, are presented in Table 4 and Table 5.

\section{Discussion}

The observed relationships between some markers of oxidative stress, and ANAs supports the hypothesis that oxidative stress may be associated with an increased likelihood of ANA formation. It is possible that oxidative stress, and the associated increase in ROS levels may initiate the formation of some autoantibodies but not others. Some ANA may be remnants of a previous local increase in 
oxidative stress in cells or tissues which has subsequently resolved. Hence we observed changes indicative of an increase in oxidative stress for only some markers.

The aim of this study was to determine whether there is an association between OS and the presence of ANA. However the data collected from participants additionally allowed us to assess whether the lifestyle factors or the lifestyle diseases affecting patients are associated with the presence of ANA. We detected ANA in $15.02 \%$ of the tested samples. This result is similar to the results obtained by others using similar cut-off thresholds $[68,90]$. Moreover, ANA were more frequently detected in women $(71.9 \%, \mathrm{p}<0.001)$, therefore in subsequent analyses we took the influence of sex into account.

In the Polish population, the prevalence of the diseases of civilisation, such as cardiovascular diseases (CVD) and often related lipid disorders, is high, and many different risk factors related to patients' lifestyles are responsible for their development [91,92]. The data presented in Table 2 show that that the occurrence of lifestyle diseases is not associated with an increased probability of developing ANA, even when sex differences are taken into account. This finding agrees with the lack of association between ANA and selected cardiovascular and metabolic diseases observed in a German population [8]. In addition, studies conducted in Japan found no association between BMI, diabetes, hypertension and the presence of ANA [93]. However, we note that for some autoantibodies, e.g. those resulting in the AC-21 pattern, there may be exceptions to this rule, as will be discussed later. We also observed that individuals who declared regular physical activity were less likely to show positive ANA ( $\mathrm{p}=0.025$ ). This observation supports the thesis, that physical activity is beneficial to the maintenance of health, and that the health benefits of exercise may extend to reducing the risk of autoantibody formation and the subsequent development of autoimmune diseases.

Surprisingly, in our cohort, women who declared cigarette smoking and alcohol drinking were less likely to have ANA ( $\mathrm{p}=0.007$ and $\mathrm{p}=0.024$ respectively) which stands in contrast to the fact that many studies have shown a linkage between smoking and the increased likelihood of autoimmune diseases, such as rheumatoid arthritis (RA), multiple sclerosis (MS), and systemic lupus erythematosus (SLE) [94-98]. Nevertheless, if we consider that the percentage of smokers is much lower in the group 
of women than in the group of men, and that women are more likely to have autoantibodies, such a surprising result may be the effect of an unfavorable combination of these two factors.

In the present study, more than three-quarters of ANA positive samples had a low antibody titer, around the cut-off level. Nevertheless, in the group of ANA positive men, a significantly lower PSH concentration and a higher MDA concentration was observed. In the case of ANA positive woman, higher UA levels and small differences in the activity of SOD isoenzymes were observed. These phenomena may support the thesis outlined in the introduction that local OS and oxidative specific epitopes (OES) formed under such conditions may play a role in the formation of autoantibodies. Interestingly, no significant changes in global OS markers such as TAC, TOS and OSI-index were observed in the study group, which may indicate the lack of active inflammatory process caused by the presence of ANA. Therefore, we cannot exclude the possibility that the observed differences only seen in some parameters of OS may indicate its local character, or may be remnants of a recently resolved increase in OS. In addition, some researchers have suggested that autoantibodies may be produced as a result of locally increased OS leading to cell death by apoptosis or necrosis $[18,99,100]$. If this is the case, the immune mechanisms involved in the production of autoantibodies might play a role in the removal of protein fragments cleaved from residues formed during cell death and tissue damage [101]. It is important to bear in mind that the development of autoimmune responses is a long-term process. It may take some time from the occurrence of an episode of increased OS and elevated ROS to result in formation of neo-antigens and for immune tolerance to these altered autoantigens to be lost, such that the production of autoantibodies is initiated.

Since mitochondria are one of the main sources of ROS in the body, we were interested to look for associations between antimitochondrial antibodies (AMA) (AC-21 pattern) and the activity of SOD isoenzymes. It is known that the mitochondrial matrix predominantly contains the manganese isoform of superoxide dismutase (MnSOD) [102,103]. Our hypothesis were not confirmed. Lower PSH levels were observed in patients with the AC-21 pattern, but this was not associated with an increased antioxidant activity of SOD in the mitochondrial matrix, compared with other ANA positive patients. Again, we can interpret this in two ways. First, there is little evidence of a real onset of OS at 
this time, but the lower PSH concentrations suggest that such an event may have occurred in the recent past. Second, it was noticed that autoantibodies associated with the AC-21 pattern type were much less frequent in the group of physically active people $(\mathrm{p}=0.005)$ and at the same time were more frequently observed in people suffering from coronary artery disease $(\mathrm{p}=0.013)$, myocardial infarction $(p=0.049)$ and dyslipidemia $(p=0.032)$. A healthy lifestyle seems to be associated with a lower likelihood of developing these autoantibodies.

Surprising results were obtained for the AC-2 pattern type. These antibodies were more frequent in patients where particular OS markers such as TAC, CuZnSOD activity and UA had lower values than in other ANA positive patients. The lower TAC is most likely due to a decrease in UA concentration. Could it be that OS has no effect on the formation of these autoantibodies? Interestingly, this type of staining pattern was the most frequently detected type in our study (50\% of all ANA positive samples). AC-2 is associated with antibodies recognizing the stress oncoprotein lens epithelium-derived growth factor p75 (LEDGF/p75), also known as dense fine speckled 70kDa (DFS70) autoantigen. Its clinical significance has not yet been established, but it occurs in apparently healthy individuals and is therefore considered a marker to exclude SARD [104]. This finding has inspired our group to perform further research in this direction, in which we intend to investigate the relationship between oxidative stress and anti DFS-70 antibodies.

\section{Limitation}

The present study is limited by the lack of data about the clinical symptoms of SARDs among the participants. So we could not compare the results obtained with any clinical manifestations. This information would allow a better analysis of the real relationship between the detected autoantibodies, OS and lifestyle factors. It may be that the lifestyle of patients in whom the presence of ANA is accompanied by a clinical manifestation of an autoimmune disease differs significantly from asymptomatic individuals. Moreover, chronic inflammation, often associated with SARD, may cause significant changes in individual oxidative stress markers.

\section{Conclusions}


The observed changes in some oxidative stress markers, in particular an increase in MDA concentration and a decrease in PSH concentration supports the hypothesis that local OS may be associated with a higher probability of ANA formation. At the same time, our data indicate that changes in individual OS markers and their association with ANA are sex-dependent and may only involve some antinuclear autoantibodies. In conclusion, we believe that there is an urgent need for further and more precise research in the field of OS as a trigger, modulator and driver of autoimmune processes. It remains to be clarified which specific autoantibodies are affected by OS and which are not. However, it seems likely that physical activity reduces the likelihood of autoantibody formation.

\section{Acknowledgments}

We would like to thank all the volunteer LIPIDOGRAM2015 investigators, all other volunteer staff and all participants. The list of the LIPIDOGRAM 2015 investigators is shown at the end of the article**.

\section{Research funding}

The present study was an initiative of the Polish Lipid Association (PoLA) and the College of Family Physicians in Poland (CFPiP). The present study was funded by an unrestricted educational grant from Valeant (Warsaw, Poland). Valeant had no role in study design, data analysis, data interpretation, or writing of the report. The present study was also supported by Silesian Analytical Laboratories (SLA), CHDE, BIO-RAD and Euroimmun.

\section{Authors' contributions}

Pawel Krzemień: Conceptualization, Methodology, Investigation, Writing - Original Draft.

Sławomir Kasperczyk: Conceptualization, Methodology, Formal analysis, Writing - Review \& Editing, Maciej Banach: Conceptualization, Methodology, Project administration, Writing - Review \& Editing Aleksandra Kasperczyk, Michał Dobrakowski, Tomasz Tomasik, Adam Windak, Mirosław Mastej, Alberico Catapano, Kausik K. Ray, Dimitri P. Mikhailidis, Peter P. Toth, George Howard, Gregory Y. H. Lip, Maciej Tomaszewski, Fadi J. Charchar, Naveed Sattar, Bryan Williams, Thomas M. MacDonald and Peter E. Penson: Writing - Review \& Editing Jacek 
J. Jóźwiak: Conceptualization, Methodology, Supervision, Project administration, Writing - Review \& Editing. All authors revised the article critically for important intellectual content. All authors gave final approval of the work have participated sufficiently in the work and take public responsibility for appropriate portions of the content.

\section{Availability of data and materials}

The datasets generated during and/or analysed during the current study are available from the corresponding author on reasonable request.

\section{Competing interests}

$\mathrm{JJJ}$ and MB have received an unrestricted educational grant from Valeant, and has served as a consultant or speaker for Valeant. PK is employed by Euroimmun Polska Sp. z o.o., (Wroclaw, Poland), whose autoantibody reagents were used in the study. PEP owns four shares in AstraZeneca PLC and has received honoraria and/or travel reimbursement for events sponsored by AKCEA, Amgen, AMRYT, Link Medical, Mylan, Napp, Sanofi. All others authors have not conflict of interest concerning the results of this analysis.

\section{Informed consent:}

Informed consent was obtained from all individuals included in this study.

\section{Ethical approval}

Research involving human subjects complied with all relevant national regulations, institutional policies and is in accordance with the tenets of the Helsinki Declaration (as revised in 2013), and has been approved by the Bioethical Committee of the Chamber of Physicians (No.K.B.Cz.-0018/2015).

\section{**LIPIDOGRAM2015 Investigators}

Al-Shaer B., Andrusewicz W., Andrzejczuk-Rosa M., Anusz-Gaszewska E., Bagińska A., Balawajder P., Bańka G., Barańska-Skubisz E., Barbara Przyczyna B., Bartkowiak S., Bartodziej J., Bartosiewicz M., Basałyga M., Batyra A., Bąk A., Bednarz M., Bejnar K., Bernacki W., Betiuk-Kwiatkowska M., 
Biegaj S., Bień M., Bilski W., Biłogan M., Biruta-Pawłowska G. Biskup A., Błaszczyk B., Błaszczyk H., Błońska-Jankowska T., Bogacka-Gancarczyk B., Bojanowska M., Bonda E., Borowik-Skwarek J., Borowska J., Bruckner J., Brzostek J., Brzuchacz M., Budzyńska M., Bulzacka-Fugiel I., Bulzak J., Bunikowski K., Cebulska A., Celka T., Cempel-Nowak E., Chechliński W., Chludzińska A., Chmiel D., Chmielewska M., Cichy M., Ciemięga A., Ciepluch A., Cieszyńska I., Czajka B., Czapla B., Czerner M., Czerwińska B., Czuryszkiewicz W., Daleka E., Dawid Z., Dąbrowska M., Dąbrowska R., Dąbrowski D., Dąbrowski M., Demczyszyn K., Dębowska-Serwińska A., Dmochowski J., DobrzeckaKiwior J., Dolanowska E., Dolanowski H., Dołek P., Domagała M., Domański H., Doszel A., Duda D., Dudkowska M., Dudziuk B., Dybciak P., Dymanowski M., Dziadzio-Bolek L., Eicke M., ElHassan H., Eremus A., Fąferek-Muller M., Figura-Roguska E., Fijałkowska-Kaczmarek I., Flis M., Florczak T., Florczuk M., Foryszewska-Witan E., Frydrych W., Fugiel A., Futyma E., GacaJaroszewicz A., Gajdamowicz I., Ganczarski K., Gatnar A., Gers M., Głowacki A., Głód K., Godula J., Gołąb J., Gołębiewski M., Goszczyńska E., Gościcka K., Górna-Hajduga A., Górny E., Grabowska T., Grabowski R., Graczyk-Duda A., Gromow A., Grudewicz A., Gruszecka J., Gruszka A., Gryboś J., Grzebyk J., Grzechowiak A., Grzesiak D., Grześkowiak T., Guźla A., Hachuła G., Hawel B., Hiltawska H., Honkowicz E., Ignatowicz J., Imielski K., Iwaniura A., Jagieła-Szymala A., Jalć-Sowała M., Janczylik A., Janisz E., Janiszek M., Jankiewicz-Ziobro K., Januszewska K., Jaremek A., JarosUrbaniak A., Jarosz J., Jarosz P., Jasiński W., Jezierska-Wasilewska M., Jędraszewski T., Jędrzejowska A., Józefowicz R., Juźwin K., Kacprzak E., Kaczmarek-Szewczyk J., Kaczmarzyk M., Kandziora R., Kaniewski C., Karolak-Brandt L., Kasperczyk S., Kasperek-Dyląg E., Kedziora I., Kępa A., Kiciński J., Kielak-Al-Hosam J., Kiełczawa Ł., Kilimowicz P., Kitliński K., Kiwka T., Klein U., Klichowicz L., Klimowicz A., Klonowski B., Kmolek B., Kobyłko-Klepacka E., Kocoń A., Kolenda A., Kollek E., Kopeć M., Koper-Kozikowska B., Koralewska J., Korczyńska M., Korzeniewski M. T., Kosk A., Kotarski K., Kowalczyk E., Kowalczyk M., Kowalik I., Kozak-Błażkiewicz B., Kozik M., Kozłowska D., Kozłowska E., Kozłowska M., Kozubski T., Kózka K., Kraśnik L., Krężel T., Krochmal B., Król B., Król G., Król J., Królikowska T., Kruszewska H., Krygier-Potrykus B., Krystek W., Krzysztoń J., Kubicki T., Kuczmierczyk-El-Hassan A., Kuczyńska-Witek W., Kujda D., Kurowski A., Kurzelewska-Solarz I., Kwaczyńska M., Kwaśniak M., Kwaśniak P., Kwietniewska T., 
Łebek-Ordon A., Lebiedowicz A., Lejkowska-Olszewska L., Lentas M., Lesiewicz-Ksycińska A., Limanowski M., Łoniewski S., Łopata J. A., Łubianka B., Łukasiuk I., Łużna M., Łysiak M., Łysik B., Machowski Z., Maciaczyk-Kubiak J., Mackiewicz-Zabochnicka G. Magner-Krężel Z., Majda S., Malinowski P., Mantyka J., Marchlik E., Martyna-Ordyniec G., Marzec J., Marzec M., MatejkoWałkiewicz R., Mazur M., Michalczak M., Michalska-Żyłka A., Michniewicz M.,Mika-Staniszewska D., Mikiciuk E., Mikołajczak T., Milewski J., Miller E., Misiaszek B., Mizik-Łukowska M., Młyńczyk-Pokutycka E., Mocek M., Moczała M., Morawska-Hermanowicz M., Moryc P., Moskal A., Moskal S., Moździerz A., Moździerz P., Mrozińska M., Mrozowicz K., Mróz G. Munia T., Mura A., Muras-Skudlarska M., Murawska E. Z., Murawski Ł., Murawski R., Musielak R., Nadaj K., Nagarnowicz W., Napierała R., Niedźwiecka M., Niemirski A., Nikiel J., Nosal M., Nowacki W., Nowak J., Nyrka M., Obst A., Ochowicz J., Ogonowska E., Oleszczyk M., Ołdakowski A., OłowniukStefaniak I., Ordowska-Rejman J., Orliński M., Osińska B., Ostańska-Burian A., Paciorkowska A., Paczkowska U., Paluch L., Pałka L., Paszko-Wojtkowska J., Paszkowska A., Pawlak-Ganczarska E., Pawlik W., Pawłowska I., Paździora M., Permiakow G. Petlic-Marendziak A., Piasecka T., Piaścińska E., Piktel A., Pilarska-Igielska A., Piotrkowska A., Piwowar-Klag K., Planer M., Plewa J., Płatkiewicz P., Płonczyńska B., Podgórska A., Polewska M., Porębska B., Porwoł P., Potakowska I., Prokop A., Przybylski J., Przybyła M., Psiuk H., Ptak K., Puzoń G. Rabiza N., Rachwalik S., Raczyńska E., Raniszewska M., Romanek-Kozik A., Rosa A., Rosa K., Rozewicz A., Rudzka-Kałwak J., Rusak J., Rutkowska D., Rybacki M., Rybińska D., Rycyk-Sadowska A., Rynda L., Rynkiewicz B., SadowskaKrawczyk B., Sadowska-Zarzycka M., Sarnecka B., Sawalach-Tomanik E., Sidor-Drozd B., Siemieniak-Dębska M., Sieroń A., Siewniak-Zalewska B., Sikora A., Sitarska-Pawlina B., Skorupski J., Skrzypińska-Mansfeld I., Skubisz J., Skwarek R., Słodyczka M., Smentek M., Smolińska K., Solarz B., Sosnowska W., Sroka B., Stachura H., Stangreciak D., Staniak M., Stańczyk Z., Stańszczak-Ozga D., Startek E., Stefańczyk M., Stelmach R., Sternadel-Rączka E., Sternik M., Stępień J., Stocka J., Stokowska-Wojda M., Studler-Karpińska M., Suchorukow W., Sufryd W., Supłacz B., Sygacz J., Szczepański Ł., Szkandera J., Szłapa-Zellner J., Szydlarska D., Śliwa T., Śliwka J., Śmiejkowski Ł., Targońska A., Tesarska E., Tobiasz M., Tomaka J., Tomalska-Bywalec K., Tomiak E., Topczewski S., Trawińska A., Trela-Mucha L., Trojanowski D., Trzaskowska M., Trzcińska-Larska B., Trznadel- 
Mozul A., Ulanicka-Liwoch K., Urbanowicz M., Uthke-Kluzek A., Waczyński J., Walczak J., Warsz L., Wasyńczuk M., Wąchała-Jędras U., Wąsowicz D., Wczysła J., Wenda F., Werner-Kubicka E., Weryszko E., Węgrzynowska B., Wiaksa M., Wiankowski M., Wicherek A., Wieczorek R., Wiencek R., Wienzek-Tatara G., Wierzbicka B., Wierzbicki M., Wilczyńska B., Wilmańska D., Winiarski P., Wiszniewska-Pabiszczak A., Witkowska M. B., Witzling J., Wlaź A., Wojtkowiak I., Woydyłło J., Woźniak K., Wójtowicz A., Wrona J., Wrońska M., Wujkowska H., Wyrąbek J., Wysokiński O., Zakrzewski R., Zaleska-Zatkalik J., Zaleski J., Zalewska- Dybciak M., Zalewska E., ZalewskaUchimiak B., Zawadzka-Krajewska J., Zawadzki J., Zieliński A., Zubrycka E., Żybort I., Żymełka M. 


\section{References:}

1. Alexovič M, Urban PL, Tabani H, Sabo J. Recent advances in robotic protein sample preparation for clinical analysis and other biomedical applications. Vol. 507, Clinica Chimica Acta. Elsevier B.V.; 2020. p. 104-16.

2. Holmes DT, Romney MG, Angel P, DeMarco ML. Proteomic applications in pathology and laboratory medicine: Present state and future prospects. Vol. 82, Clinical Biochemistry. Elsevier Inc.; 2020. p. 12-20.

3. Hayter SM, Cook MC. Updated assessment of the prevalence, spectrum and case definition of autoimmune disease [Internet]. Autoimmunity Reviews. 2012. https://doi.org/10.1016/j.autrev.2012.02.001

4. Rosenblum MD, Remedios KA, Abbas AK. Mechanisms of human autoimmunity. J Clin Invest. 2015;

5. Tan EM, Feltkamp TEW, Smolen JS, Butcher B, Dawkins R, Fritzler MJ, et al. Range of antinuclear antibodies in "healthy" individuals. Arthritis Rheum. 1997;40(9):1601-11. https://doi.org/10.1002/art.1780400909

6. Grygiel-Górniak B, Rogacka N, Puszczewicz M. Antinuclear antibodies in healthy people and non-rheumatic diseases - diagnostic and clinical implications. Reumatologia/Rheumatology. 2018;56(4):243-8. https://www.termedia.pl/doi/10.5114/reum.2018.77976

7. Mahler M, Parker T, Peebles CL, Andrade LE, Swart A, Carbone Y, et al. Anti-DFS70/LEDGF antibodies are more prevalent in healthy individuals compared to patients with systemic autoimmune rheumatic diseases. J Rheumatol. 2012;

8. Akmatov MK, Röber N, Ahrens W, Flesch-Janys D, Fricke J, Greiser H, et al. Anti-nuclear autoantibodies in the general German population: prevalence and lack of association with selected cardiovascular and metabolic disorders-findings of a multicenter population-based study. Arthritis Res Ther. 2017;19(1):127. http://arthritis- 
research.biomedcentral.com/articles/10.1186/s13075-017-1338-5

9. Rose NR. Autoimmune Diseases. In: International Encyclopedia of Public Health. 2016.

10. Ngo ST, Steyn FJ, McCombe PA. Gender differences in autoimmune disease. Front Neuroendocrinol. 2014;35(3):347-69. http://dx.doi.org/10.1016/j.yfrne.2014.04.004

11. Anaya JM. Common mechanisms of autoimmune diseases (the autoimmune tautology). Autoimmunity Reviews. 2012.

12. Marson A, Housley WJ, Hafler DA. Genetic basis of autoimmunity. J Clin Invest. 2015;125(6):2234-41.

13. Peng Y, Kowalewski R, Kim S, Elkon KB. The role of IgM antibodies in the recognition and clearance of apoptotic cells. In: Molecular Immunology. 2005.

14. Mũoz LE, Lauber K, Schiller M, Manfredi AA, Herrmann M. The role of defective clearance of apoptotic cells in systemic autoimmunity. Nature Reviews Rheumatology. 2010.

15. Kuhn A, Wenzel J, Weyd H. Photosensitivity, Apoptosis, and Cytokines in the Pathogenesis of Lupus Erythematosus: a Critical Review. Clinical Reviews in Allergy and Immunology. 2014.

16. Miller YI, Choi SH, Wiesner P, Fang L, Harkewicz R, Hartvigsen K, et al. Oxidation-specific epitopes are danger-associated molecular patterns recognized by pattern recognition receptors of innate immunity. Circ Res. 2011;108(2):235-48.

17. Peng YF, Martin DA, Kenkel J, Zhang K, Ogden CA, Elkon KB. Innate and adaptive immune response to apoptotic cells. Journal of Autoimmunity. 2007.

18. Tyurin VA, Tyurina YY, Ritov VB, Lysytsya A, Amoscato AA, Kochanek PM, et al. Oxidative lipidomics of apoptosis: quantitative assessment of phospholipid hydroperoxides in cells and tissues. Methods Mol Biol. 2010;

19. Root-Bernstein R, Fairweather DL. Complexities in the relationship between infection and 
autoimmunity. Current allergy and asthma reports. 2014.

20. Sfriso P, Ghirardello A, Botsios C, Tonon M, Zen M, Bassi N, et al. Infections and autoimmunity: the multifaceted relationship. J Leukoc Biol. 2010;

21. Speyer CB, Costenbader KH. Cigarette smoking and the pathogenesis of systemic lupus erythematosus. Vol. 14, Expert Review of Clinical Immunology. Taylor and Francis Ltd; 2018. p. $481-7$.

22. Souliotis VL, Vlachogiannis NI, Pappa M, Argyriou A, Ntouros PA, Sfikakis PP. DNA Damage Response and Oxidative Stress in Systemic Autoimmunity. Int J Mol Sci. 2019;21(1):55. https://www.mdpi.com/1422-0067/21/1/55

23. Kurien BT, Hensley K, Bachmann M, Scofield RH. Oxidatively modified autoantigens in autoimmune diseases. Free Radical Biology and Medicine. 2006.

24. Kannan S. Free radical theory of autoimmunity. Theor Biol Med Model. 2006;3:1-16. https://tbiomed.biomedcentral.com/articles/10.1186/1742-4682-3-22

25. Ali R, Ahsan H, Ali A, Ali R. Oxygen free radicals and systemic autoimmunity. Vol. 131, Clin Exp Immunol. 2003.

26. Smallwood MJ, Nissim A, Knight AR, Whiteman M, Haigh R, Winyard PG. Oxidative stress in autoimmune rheumatic diseases. Free Radic Biol Med. 2018;125(May):3-14. https://doi.org/10.1016/j.freeradbiomed.2018.05.086

27. Chang C, Gershwin ME. Drugs and autoimmunity - A contemporary review and mechanistic approach. J Autoimmun. 2010;34(3).

28. Yahyapour R, Amini P, Rezapour S, Cheki M, Rezaeyan A, Farhood B, et al. Radiationinduced inflammation and autoimmune diseases. Mil Med Res. 2018;5(1):1-8.

29. Hussain MS, Tripathi V. Smoking under hypoxic conditions: a potent environmental risk factor for inflammatory and autoimmune diseases. Mil Med Res. 2018;5(1):11. 
https://mmrjournal.biomedcentral.com/articles/10.1186/s40779-018-0158-5

30. Salihoglu S, Dogan SC, Kavakci O. Effects of childhood psychological trauma on rheumatic diseases. Eur J Rheumatol. 2019;6(3):126-9. https://eurjrheumatol.org//en/effects-ofchildhood-psychological-trauma-on-rheumatic-diseases-133226

31. Elkon K, Casali P. Nature and functions of autoantibodies. Nat Clin Pract Rheumatol. 2008;4(9):491-8.

32. Eggleton P, Haigh R, Winyard PG. Consequence of neo-antigenicity of the "altered self." Rheumatology. 2008.

33. Ludwig RJ, Vanhoorelbeke K, Leypoldt F, Kaya Z, Bieber K, McLachlan SM, et al. Mechanisms of autoantibody-induced pathology. Front Immunol. 2017;8(MAY).

34. Duan B, Morel L. Role of B-1a cells in autoimmunity. Autoimmunity Reviews. 2006.

35. Tsiantoulas D, Gruber S, Binder CJ. B-1 cell immunoglobulin directed against oxidationspecific epitopes. Front Immunol. 2012;3(JAN):1-6.

36. Abbas AK, Lohr J, Knoechel B, Nagabhushanam V. T cell tolerance and autoimmunity. Autoimmunity Reviews. 2004.

37. Von Herrath MG, Harrison LC. Antigen-induced regulatory T cells in autoimmunity. Nature Reviews Immunology. 2003.

38. Romagnani S. Immunological tolerance and autoimmunity. Intern Emerg Med. 2006;

39. Tobón GJ, Izquierdo JH, Cañas CA. B lymphocytes: Development, tolerance, and their role in autoimmunity - Focus on systemic lupus erythematosus. Autoimmune Diseases. 2013.

40. Ryan BJ, Nissim A, Winyard PG. Oxidative post-translational modifications and their involvement in the pathogenesis of autoimmune diseases. Redox Biol. 2014;2(1):715-24. http://dx.doi.org/10.1016/j.redox.2014.05.004 
41. Scofield RH, Kurien BT, Ganick S, McClain MT, Pye Q, James JA, et al. Modification of lupus-associated 60-kDa Ro protein with the lipid oxidation product 4-hydroxy-2-nonenal increases antigenicity and facilitates epitope spreading. Free Radic Biol Med. 2005;

42. Chou MY, Hartvigsen K, Hansen LF, Fogelstrand L, Shaw PX, Boullier A, et al. Oxidationspecific epitopes are important targets of innate immunity. In: Journal of Internal Medicine. 2008.

43. Kalluri R, Cantley LG, Kerjaschki D, Neilson EG. Reactive oxygen species expose cryptic epitopes associated with autoimmune Goodpasture syndrome. J Biol Chem. 2000;

44. Chou MY, Fogelstrand L, Hartvigsen K, Hansen LF, Woelkers D, Shaw PX, et al. Oxidationspecific epitopes are dominant targets of innate natural antibodies in mice and humans. J Clin Invest. 2009;119(5):1335-49.

45. Binder CJ. Natural IgM antibodies against oxidation-specific epitopes. Journal of Clinical Immunology. 2010.

46. Chang MK, Binder CJ, Miller YI, Subbanagounder G, Silverman GJ, Berliner JA, et al. Apoptotic cells with oxidation-specific epitopes are immunogenic and proinflammatory. J Exp Med. 2004;200(11):1359-70.

47. Papac-Milicevic N, Busch CJL, Binder CJ. Malondialdehyde Epitopes as Targets of Immunity and the Implications for Atherosclerosis. In: Advances in Immunology. 2016.

48. Zarkovic N, Cipak A, Jaganjac M, Borovic S, Zarkovic K. Pathophysiological relevance of aldehydic protein modifications. Journal of Proteomics. 2013.

49. Servettaz A, Guilpain P, Goulvestre C, Chéreau C, Hercend C, Nicco C, et al. Radical oxygen species production induced by advanced oxidation protein products predicts clinical evolution and response to treatment in systemic sclerosis. Ann Rheum Dis. 2007;

50. Piwowar A. The advanced oxidation protein products as potential diagnostic and prognostic 
factor in diseases of the indicated participation of oxidative stress. Postepy Hig Med Dosw. 2014;68:446-58.

51. STADTMAN ER, LEVINE RL. Protein Oxidation. Ann N Y Acad Sci. 2006;

52. Weismann D, Binder CJ. The innate immune response to products of phospholipid peroxidation. Biochimica et Biophysica Acta - Biomembranes. 2012.

53. Kurien BT, Scofield RH. Autoimmunity and oxidatively modified autoantigens. Autoimmun Rev. 2008;7(7):567-73.

54. Buttari B, Profumo E, Mattei V, Siracusano A, Ortona E, Margutti P, et al. Oxidized $\beta 2$ glycoprotein I induces human dendritic cell maturation and promotes a T helper type 1 response. Blood. 2005;

55. Wang G, Pierangeli SS, Papalardo E, Ansari GAS, Khan MF. Markers of oxidative and nitrosative stress in systemic lupus erythematosus: Correlation with disease activity. Arthritis Rheum. 2010;

56. Kavian N, Servettaz A, Mongaret C, Wang A, Nicco C, Chéreau C, et al. Targeting ADAM17/notch signaling abrogates the development of systemic sclerosis in a murine model. Arthritis Rheum. 2010;62(11):3477-87.

57. Hardt U, Larsson A, Gunnarsson I, Clancy RM, Petri M, Buyon JP, et al. Autoimmune reactivity to malondialdehyde adducts in systemic lupus erythematosus is associated with disease activity and nephritis. Arthritis Res Ther. 2018;20(1):1-12.

58. Gargouri B, Mseddi M, Mnif F, Abid M, Attia H, Lassoued S. Oxidative stress enhances the immune response to oxidatively modified catalase enzyme in patients with Graves' disease. J Clin Lab Anal. 2019;(September):1-6.

59. Eggleton P, Nissim A, Ryan BJ, Whiteman M, Winyard PG. Detection and isolation of human serum autoantibodies that recognize oxidatively modified autoantigens. Free Radical Biology 
and Medicine. 2013.

60. Manzi S. Cardiovascular Disease in Systemic Lupus Erythematosus. In: Systemic Lupus Erythematosus: Basic, Applied and Clinical Aspects. 2016.

61. Svenungsson E, Jensen-Urstad K, Heimbürger M, Silveira A, Hamsten A, De Faire U, et al. Risk factors for cardiovascular disease in systemic lupus erythematosus. Circulation. 2001;

62. Otaki N, Chikazawa M, Nagae R, Shimozu Y, Shibata T, Ito S, et al. Identification of a lipid peroxidation product as the source of oxidation-specific epitopes recognized by anti-DNA autoantibodies. J Biol Chem. 2010;285(44):33834-42.

63. Servettaz A, Goulvestre C, Kavian N, Nicco C, Guilpain P, Chéreau C, et al. Selective Oxidation of DNA Topoisomerase 1 Induces Systemic Sclerosis in the Mouse. J Immunol. 2009;

64. Wang G, Wang J, Fan X, Ansari GAS, Khan MF. Protein adducts of malondialdehyde and 4hydroxynonenal contribute to trichloroethene-mediated autoimmunity via activating Th17 cells: Dose- and time-response studies in female MRL+/+ mice. Toxicology. 2012;

65. Avery TY, Van De Cruys M, Austen J, Stals F, Damoiseaux JGMC. Anti-nuclear antibodies in daily clinical practice: Prevalence in primary, secondary, and tertiary care. J Immunol Res. 2014;2014:25-30.

66. Damoiseaux J, Olschowka N, Shoenfeld Y. EASI - European Autoimmunity Standardisation Initiative: Facing the challenges of diagnostics in autoimmunity. Clin Chem Lab Med. 2018;56(10):1620-3.

67. Damoiseaux J, Andrade LEC, Carballo OG, Conrad K, Francescantonio PLC, Fritzler MJ, et al. Clinical relevance of HEp-2 indirect immunofluorescent patterns: the International Consensus on ANA patterns (ICAP) perspective. Ann Rheum Dis. 2019;78(7):879-89. https://ard.bmj.com/lookup/doi/10.1136/annrheumdis-2018-214436 
68. Agmon-Levin N, Damoiseaux J, Kallenberg C, Sack U, Witte T, Herold M, et al. International recommendations for the assessment of autoantibodies to cellular antigens referred to as antinuclear antibodies. Ann Rheum Dis. 2014;73(1):17-23. https://ard.bmj.com/lookup/doi/10.1136/annrheumdis-2013-203863

69. Chan EKL, Damoiseaux J, Carballo OG, Conrad K, de Melo Cruvinel W, Francescantonio PLC, et al. Report of the First International Consensus on Standardized Nomenclature of Antinuclear Antibody HEp-2 Cell Patterns (ICAP) 2014-2015. Front Immunol. 2015;6(JUL):1-13.

70. Wiik AS, Høier-Madsen M, Forslid J, Charles P, Meyrowitsch J. Antinuclear antibodies: A contemporary nomenclature using HEp-2 cells. J Autoimmun. 2010;

71. Mariz HA, Sato EI, Barbosa SH, Rodrigues SH, Dellavance A, Andrade LEC. Pattern on the antinuclear antibody-HEp-2 test is a critical parameter for discriminating antinuclear antibodypositive healthy individuals and patients with autoimmune rheumatic diseases. Arthritis Rheum. 2011;63(1):191-200. http://doi.wiley.com/10.1002/art.30084

72. Przywara-Chowaniec B, Seget S, Dróżdż M, Puzio A, Czuba Z, Nowalany-Kozielska E, et al. Ocena stanu antyoksydacyjnego w wybranych chorobach układowych tkanki łącznej. Ann Acad Medicae Silesiensis. 2018;72:116-20. http://annales.sum.edu.pl/archiwum_publikacje/16_2018.pdf

73. Mateen S, Moin S, Khan AQ, Zafar A, Fatima N. Increased reactive oxygen species formation and oxidative stress in rheumatoid arthritis. PLoS One. 2016;11(4):1-15.

74. Luo JY, Liu X, Jiang M, Zhao HP, Zhao JJ. Oxidative stress markers in blood in systemic sclerosis: A meta-analysis. Mod Rheumatol. 2017;

75. Staroń A, Mąkosa G, Koter-Michalak M. Oxidative stress in erythrocytes from patients with rheumatoid arthritis. Rheumatol Int. 2012;32(2):331-4.

76. Tetik S, Ahmad S, Alturfan AA, Fresko I, Disbudak M, Sahin Y, et al. Determination of 
oxidant stress in plasma of rheumatoid arthritis and primary osteoarthritis patients. Indian J Biochem Biophys. 2010;

77. Zhang Q, Ye DQ, Chen GP, Zheng Y. Oxidative protein damage and antioxidant status in systemic lupus erythematosus. Clin Exp Dermatol. 2010;

78. Lee HT, Wu TH, Lin CS, Lee CS, Wei YH, Tsai CY, et al. The pathogenesis of systemic lupus erythematosus - From the viewpoint of oxidative stress and mitochondrial dysfunction. Mitochondrion. 2016.

79. Lee HT, Lin CS, Lee CS, Tsai CY, Wei YH. Increased 8-hydroxy-2'-deoxyguanosine in plasma and decreased mRNA expression of human 8-oxoguanine DNA glycosylase 1, antioxidant enzymes, mitochondrial biogenesis-related proteins and glycolytic enzymes in leucocytes in patients with systemic lupus ery. Clin Exp Immunol. 2014;

80. Desai PB, Manjunath S, Sumangala K, Chetana K, Vanishree J. Oxidative stress and enzymatic antioxidant status in rheumatoid arthritis: A case control study. Eur Rev Med Pharmacol Sci. 2010;

81. Jóźwiak JJ, Kasperczyk S, Tomasik T, Osadnik T, Windak A, Studziński K, et al. Manuscript body Design and rationale of a nationwide screening analysis from the LIPIDOGRAM2015 and LIPIDOGEN2015 study. Arch Med Sci. 2020;16(5):1-13. https://doi.org/10.5114/aoms.2020.96052

82. Erel O. A new automated colorimetric method for measuring total oxidant status. Clin Biochem. 2005;38(12):1103-11.

83. Koster JF, Biemond P, Swaak AJG. Intracellular and extracellular sulphydryl levels in rheumatoid arthritis. Ann Rheum Dis. 1986;45(1):44-6.

84. Ohkawa H, Ohishi N, Yagi K. Assay for lipid peroxides in animal tissues by thiobarbituric acid reaction. Anal Biochem. 1979;95(2):351-8. 
85. Oyanagui Y. Reevaluation of assay methods and establishment of kit for superoxide dismutase activity. Anal Biochem. 1984;142(2):290-6.

86. Erel O. A novel automated direct measurement method for total antioxidant capacity using a new generation, more stable ABTS radical cation. Clin Biochem. 2004;37(4):277-85.

87. Association WM. World Medical Association declaration of Helsinki: Ethical principles for medical research involving human subjects [Internet]. Vol. 310, JAMA - Journal of the American Medical Association. American Medical Association; 2013. p. 2191-4. www.jama.com.

88. WHO/Europe | Nutrition - Body mass index - BMI [Internet]. http://www.euro.who.int/en/health-topics/disease-prevention/nutrition/a-healthy-lifestyle/bodymass-index-bmi

89. Nishida C, Ko GT, Kumanyika S. Body fat distribution and noncommunicable diseases in populations: Overview of the 2008 WHO Expert Consultation on Waist Circumference and Waist-Hip Ratio [Internet]. Vol. 64, European Journal of Clinical Nutrition. 2010. p. 2-5. http://www.nature.com/articles/ejcn2009139

90. Prüßmann J, Prüßmann W, Recke A, Rentzsch K, Juhl D, Henschler R, et al. Co-occurrence of autoantibodies in healthy blood donors. Exp Dermatol. 2014;23(7):519-21. http://doi.wiley.com/10.1111/exd.12445

91. Jóźwiak JJ, Studziński K, Tomasik T, Windak A, Mastej M, Catapano AL, et al. The prevalence of cardiovascular risk factors and cardiovascular disease among primary care patients in Poland: results from the LIPIDOGRAM2015 study. Atheroscler Suppl. 2020;42:e15-24.

92. Harrison SL, Lane DA, Banach M, Mastej M, Kasperczyk S, Jóźwiak JJ, et al. Lipid levels, atrial fibrillation and the impact of age: Results from the LIPIDOGRAM2015 study. Atherosclerosis. 2020;312:16-22. http://www.atherosclerosis- 
journal.com/article/S0021915020304822/fulltext

93. Ishikawa M, Konta T, Hao Z, Takasaki S, Abiko H, Takahashi T, et al. Relationship between antinuclear antibody and microalbuminuria in the general population: The Takahata study. Clin Exp Nephrol. 2008;

94. Arnson Y, Shoenfeld Y, Amital H. Effects of tobacco smoke on immunity, inflammation and autoimmunity. J Autoimmun. 2010;34(3):J258-65. https://linkinghub.elsevier.com/retrieve/pii/S0896841109001620

95. Perricone C, Versini M, Ben-Ami D, Gertel S, Watad A, Segel MJ, et al. Smoke and autoimmunity: The fire behind the disease. Autoimmunity Reviews. 2016.

96. Barbhaiya M, Tedeschi SK, Lu B, Malspeis S, Kreps D, Jeffrey A, et al. Cigarette Smoking and the Risk of Systemic Lupus Erythematosus, Overall and by Anti-Double Stranded DNA Antibody Subtype, in the Nurses' Health Study Cohorts Medha. 2018;77(2):196-202.

97. Pham-Huy LA, He H, Pham-Huy C. Free radicals, antioxidants in disease and health. Int J Biomed Sci. 2008;4(2):89-96.

98. Freemer MM, King TE, Criswell LA. Association of smoking with dsDNA autoantibody production in systemic lupus erythematosus. Ann Rheum Dis. 2006;

99. Circu ML, Aw TY. Reactive oxygen species, cellular redox systems, and apoptosis. Free Radic Biol Med. 2010;48(6):749-62. http://dx.doi.org/10.1016/j.freeradbiomed.2009.12.022

100. Kujoth CC, Hiona A, Pugh TD, Someya S, Panzer K, Wohlgemuth SE, et al. Medicine: Mitochondrial DNA mutations, oxidative stress, and apoptosis in mammalian aging. Science (80- ). 2005;

101. Infantino M, Carbone T, Manfredi M, Grossi V, Benucci M, Blank M, et al. Are Anti-DFS70 Autoantibodies Protective? Isr Med Assoc J. 2019;21(8):509-11. http://www.ncbi.nlm.nih.gov/pubmed/31474007 
102. Twardoch M, Lodwich M, Mazur B. Allergy and Oxidative Stress. Ann Acad Medicae Silesiensis. 2016;70:15-23.

103. Birben E, Sahiner UM, Sackesen C, Erzurum S, Kalayci O. Oxidative stress and antioxidant defense. World Allergy Organization Journal. 2012.

104. Seelig CA, Bauer O, Seelig HP. Autoantibodies against DFS70/LEDGF exclusion markers for systemic autoimmune rheumatic diseases (SARD). Clinical Laboratory. 2016. 
Table 1. Characteristics of the population.

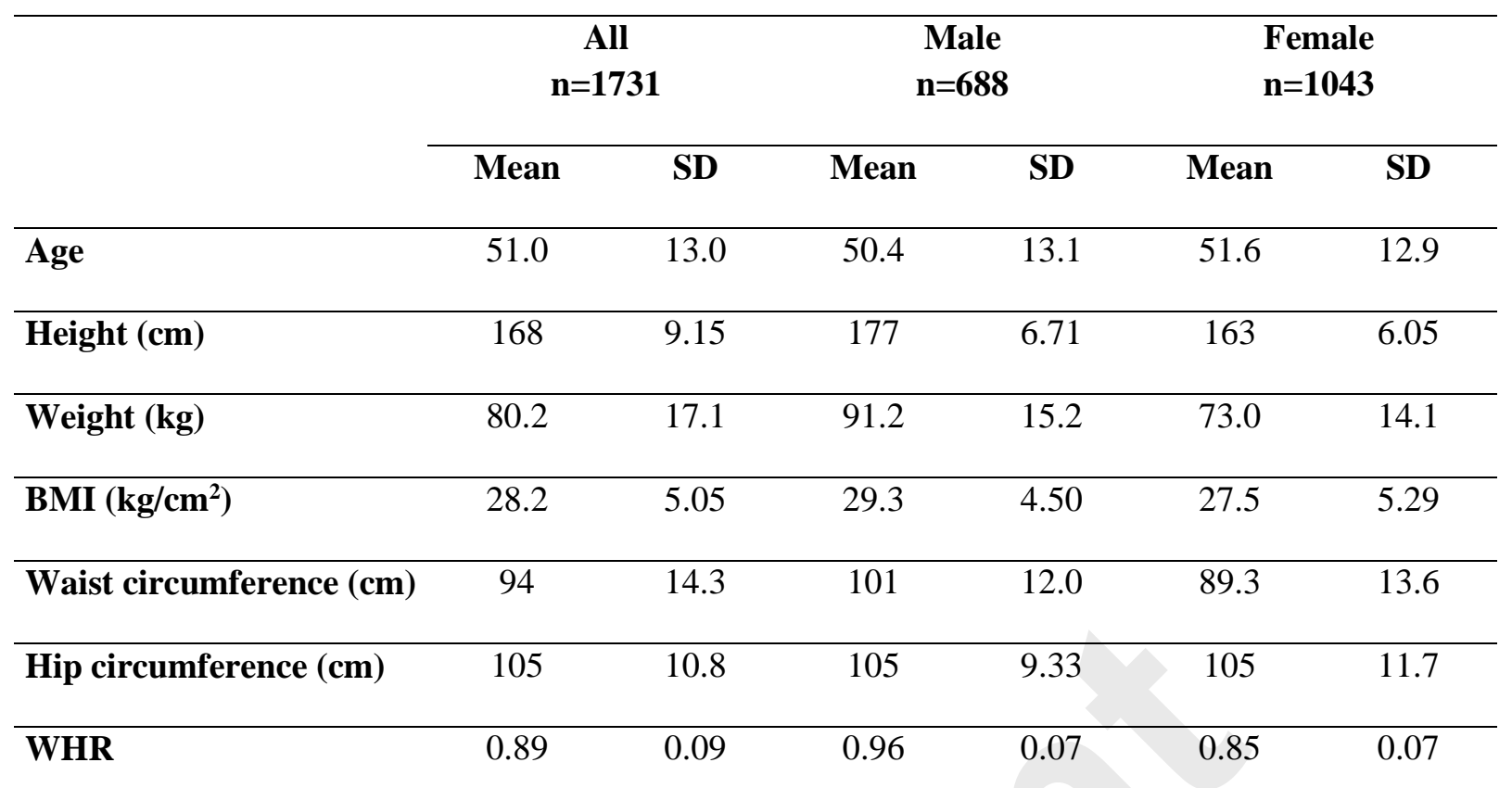

BMI - body mass index, WHR - waist-hip ratio, 
Table 2. The occurrence of ANA in relation to lifestyle factors.

\begin{tabular}{|c|c|c|c|c|c|c|c|c|c|c|c|c|c|c|c|}
\hline & \multicolumn{5}{|c|}{ All participants $n=1731$} & \multicolumn{5}{|c|}{ Male $n=688$} & \multicolumn{5}{|c|}{ Female $n=1043$} \\
\hline & \multicolumn{2}{|c|}{$\begin{array}{c}\text { ANA } \\
\text { negative } \\
\text { n=1471 }\end{array}$} & \multicolumn{2}{|c|}{$\begin{array}{c}\text { ANA } \\
\text { positive } \\
\mathbf{n}=260\end{array}$} & \multirow[b]{2}{*}{ p-value } & \multicolumn{2}{|c|}{$\begin{array}{c}\text { ANA } \\
\text { negative } \\
n=615\end{array}$} & \multicolumn{2}{|c|}{$\begin{array}{c}\text { ANA } \\
\text { positive } \\
n=73\end{array}$} & \multirow[b]{2}{*}{ p-value } & \multicolumn{2}{|c|}{$\begin{array}{c}\text { ANA } \\
\text { negative } \\
\text { n=856 }\end{array}$} & \multicolumn{2}{|c|}{$\begin{array}{c}\text { ANA } \\
\text { positive } \\
\text { n=187 }\end{array}$} & \\
\hline & $\%$ & $\mathbf{n}$ & $\%$ & $\mathbf{n}$ & & $\%$ & n & $\%$ & $\mathrm{n}$ & & $\%$ & $\mathbf{n}$ & $\%$ & $\mathbf{n}$ & p-value \\
\hline Sex (\% of men) & $41.8 \%$ & 615 & $28.1 \%$ & 73 & $<0.001$ & & & & 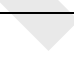 & & & & & & \\
\hline $\begin{array}{l}\text { Physical activity } \\
\text { (use of regular physical effort) }\end{array}$ & $44.8 \%$ & 659 & $37.3 \%$ & 97 & 0.025 & $47.2 \%$ & 290 & $43.8 \%$ & 32 & 0.592 & $43.1 \%$ & 369 & $34.8 \%$ & 65 & 0.036 \\
\hline $\begin{array}{l}\text { Dietary habits } \\
\text { (use of an appropriate diet) }\end{array}$ & $67.4 \%$ & 992 & $63.8 \%$ & 166 & 0.257 & $72.4 \%$ & 445 & $67.1 \%$ & 49 & 0.348 & $63.9 \%$ & 547 & $62.6 \%$ & 117 & 0.731 \\
\hline $\begin{array}{l}\text { Tobacco Smoking } \\
\text { (current smokers) }\end{array}$ & $65.2 \%$ & 959 & $49.2 \%$ & 128 & 0.001 & $76.9 \%$ & 473 & $71.2 \%$ & 52 & 0.531 & $56.8 \%$ & 486 & $40.6 \%$ & 76 & 0.007 \\
\hline $\begin{array}{l}\text { Alcohol consumption (moderate or } \\
\text { heavy drinkers) }\end{array}$ & $16.9 \%$ & 249 & $11.2 \%$ & 29 & 0.019 & $18.0 \%$ & 111 & $15.1 \%$ & 11 & 0.529 & $16.1 \%$ & 138 & $9.6 \%$ & 18 & 0.024 \\
\hline Chronic kidney disease & $2.7 \%$ & 40 & $1.5 \%$ & 4 & 0.265 & $2.3 \%$ & 14 & $1.4 \%$ & 1 & 0.617 & $3.0 \%$ & 26 & $1.6 \%$ & 3 & 0.281 \\
\hline Coronary artery disease & $10.3 \%$ & 152 & $11.2 \%$ & 29 & 0.690 & $13.5 \%$ & 83 & $12.3 \%$ & 9 & 0.782 & $8.1 \%$ & 69 & $10.7 \%$ & 20 & 0.243 \\
\hline
\end{tabular}




\begin{tabular}{|c|c|c|c|c|c|c|c|c|c|c|c|c|c|c|c|}
\hline Myocardial infarction & $4.1 \%$ & 61 & $4.2 \%$ & 11 & 0.950 & $7.6 \%$ & 47 & $8.2 \%$ & 6 & 0.862 & $1.6 \%$ & 14 & $2.7 \%$ & 5 & 0.337 \\
\hline Ischemic stroke & $1.5 \%$ & 22 & $1.9 \%$ & 5 & 0.608 & $2.1 \%$ & 13 & $1.4 \%$ & 1 & 0.671 & $1.1 \%$ & 9 & $2.1 \%$ & 4 & 0.225 \\
\hline Haemorrhagic stroke & $0.3 \%$ & 4 & $0.4 \%$ & 1 & 0.755 & $0.3 \%$ & 2 & $1.4 \%$ & 1 & 0.201 & $0.2 \%$ & 2 & $0.0 \%$ & 0 & 0.509 \\
\hline Atrial fibrillation & $2.8 \%$ & 41 & $4.2 \%$ & 11 & 0.209 & $2.6 \%$ & 16 & $4.1 \%$ & 3 & 0.458 & $2.9 \%$ & 25 & $4.3 \%$ & 8 & 0.337 \\
\hline Dyslipidemia & $49.4 \%$ & 726 & $51.9 \%$ & 135 & 0.445 & $54.8 \%$ & 337 & $60.3 \%$ & 44 & 0.374 & $45.4 \%$ & 389 & $48.7 \%$ & 91 & 0.424 \\
\hline Family hypercholesterolemia & $3.7 \%$ & 55 & $2.3 \%$ & 6 & 0.249 & $3.6 \%$ & 22 & $4.1 \%$ & 3 & 0.819 & $3.9 \%$ & 33 & $1.6 \%$ & 3 & 0.127 \\
\hline Diabetes mellitus & $15.6 \%$ & 229 & $19.2 \%$ & 50 & 0.139 & $19.5 \%$ & 120 & $26.0 \%$ & 19 & 0.190 & $12.7 \%$ & 109 & $16.6 \%$ & 31 & 0.163 \\
\hline Arterial hypertension & $42.1 \%$ & 619 & $47.7 \%$ & 124 & 0.092 & $47.8 \%$ & 294 & $56.2 \%$ & 41 & 0.177 & $38.0 \%$ & 325 & $44.4 \%$ & 83 & 0.103 \\
\hline Healthy individuals & $36.3 \%$ & 534 & $38.1 \%$ & 99 & 0.584 & $30.9 \%$ & 190 & $27.4 \%$ & 20 & 0.540 & $40.2 \%$ & 344 & $42.2 \%$ & 79 & 0.604 \\
\hline
\end{tabular}

ANA - anti-nuclear antibody, 
Table 3. Levels of oxidative stress markers in ANA positive and negative individuals.

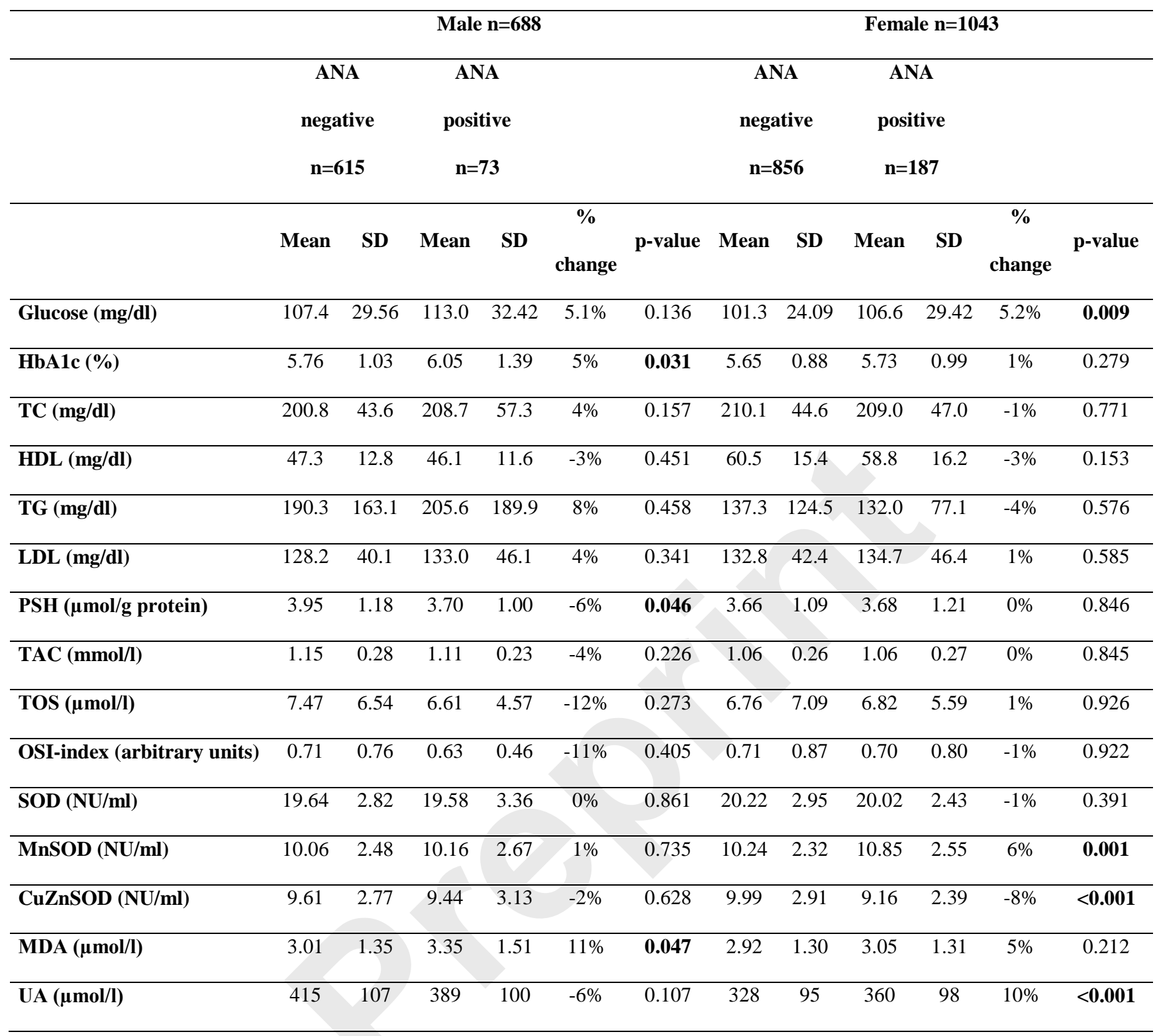

ANA - anti-nuclear antibody, HbA1c - Hemoglobin A1c, HDL - high-density lipoprotein cholesterol, LDL - low-density lipoprotein cholesterol, MDA - malondialdehyde, OSI-index - oxidative stress index, PSH - protein thiol groups, SOD - superoxide dismutase, TAC - total antioxidant capacity, TC - total cholesterol, TG triglycerides, TOS - total oxidant status, UA - uric acid 
Table 4. The relationship between selected lifestyle factors and ANA pattern staining.

ANA positive

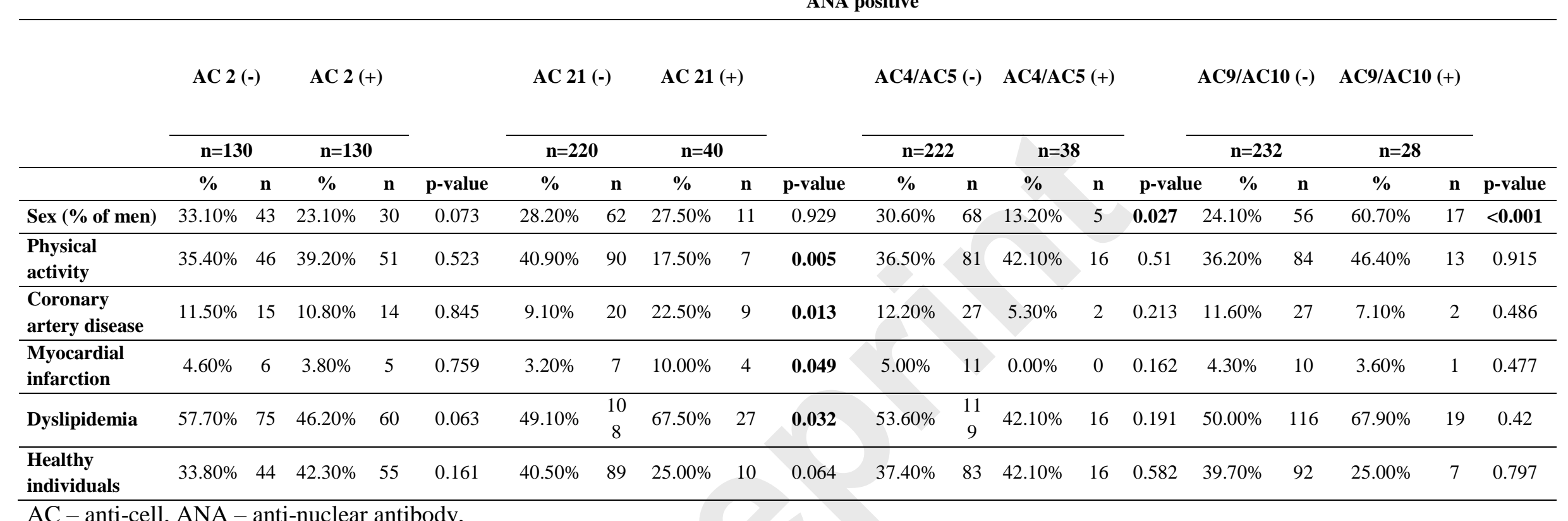


Table 5. The relationship between oxidative stress markers and ANA pattern staining.

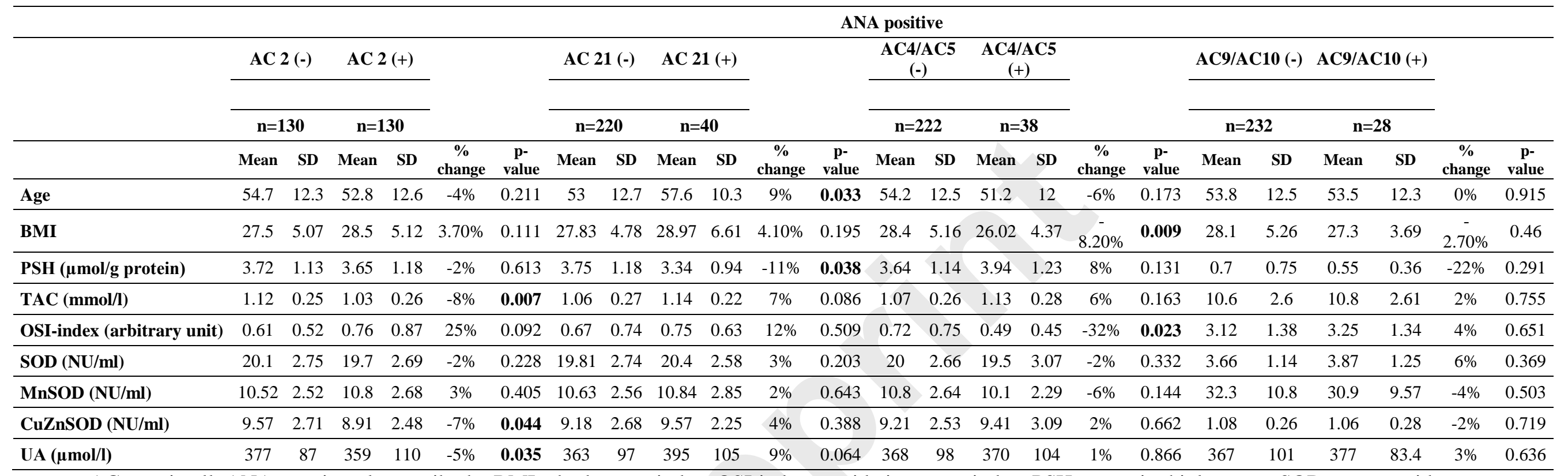

AC - anti-cell, ANA - anti-nuclear antibody, BMI - body mass index, OSI-index - oxidative stress index, PSH - protein thiol groups, SOD - superoxide dismutase, TAC - total antioxidant capacity, UA - uric acid 


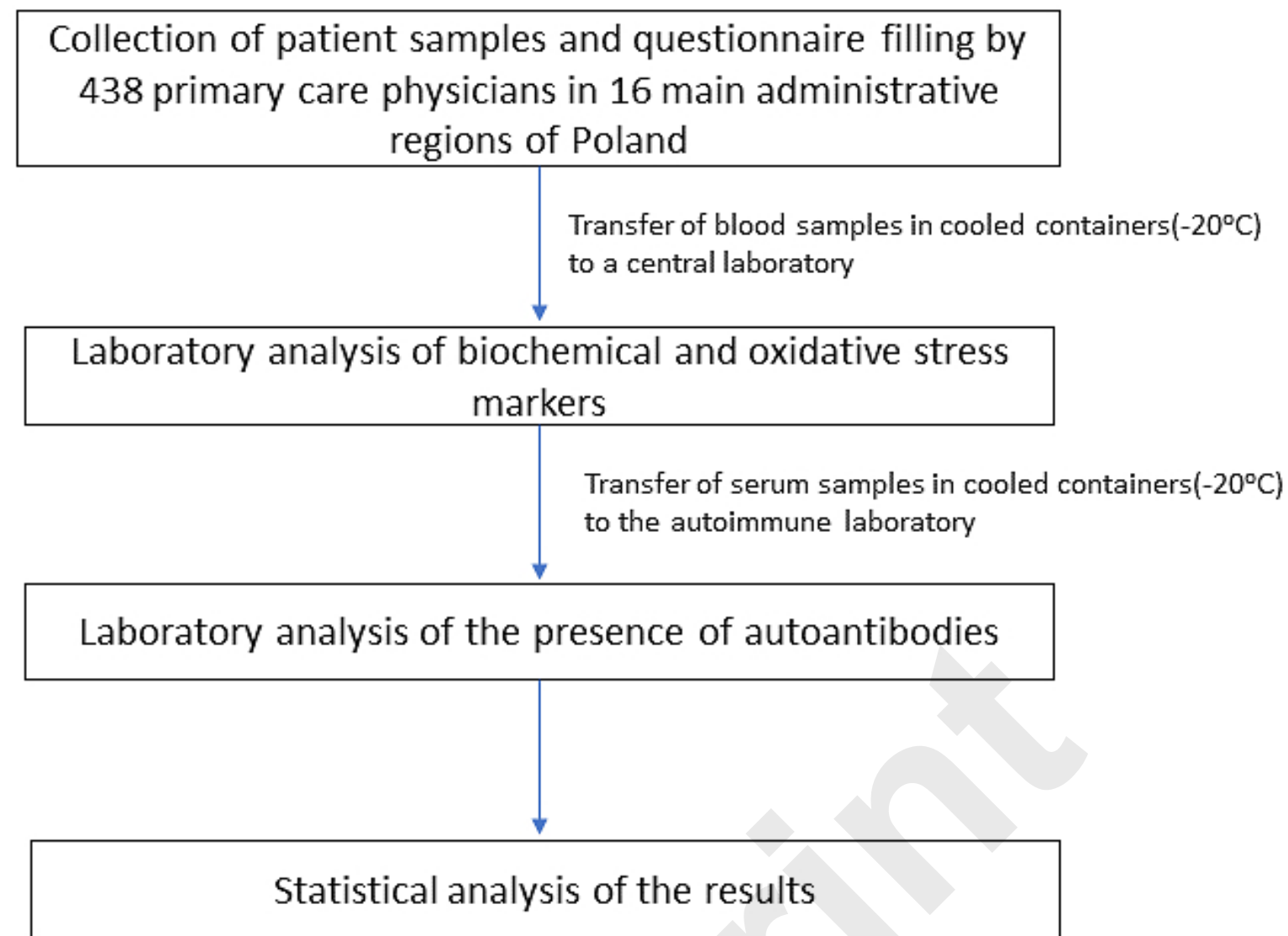

Figure 1. Research procedural stages 